\title{
Wastelands, Greenways and Gentrification: Introducing a Comparative Framework with a Focus on Detroit, USA
}

\author{
Paul Draus ${ }^{1}$, Dagmar Haase ${ }^{2}\left(\mathbb{D}\right.$, Jacob Napieralski ${ }^{3}{ }^{\oplus}$, Alec Sparks ${ }^{4}$, Salman Qureshi ${ }^{2, *}(\mathbb{C}$ \\ and Juliette Roddy ${ }^{5}$ \\ 1 Department of Behavioral Sciences, The University of Michigan-Dearborn, 4901 Evergreen Rd., \\ Dearborn, MI 48128, USA; draus@umich.edu \\ 2 Institute of Geography, Humboldt University Berlin, Rudower Chaussee 16, 12489 Berlin, Germany; \\ dagmar.haase@ufz.de \\ 3 Department of Natural Sciences, The University of Michigan-Dearborn, 4901 Evergreen Rd., \\ Dearborn, MI 48128, USA; jnapiera@umich.edu \\ 4 Department of Social Sciences, The University of Michigan-Dearborn, 4901 Evergreen Rd., \\ Dearborn, MI 48128, USA; sparksa@umich.edu \\ 5 Department of Criminology and Criminal Justice, Northern Arizona University, Flagstaff, AZ 86005, USA; \\ juliette.roddy@nau.edu \\ * Correspondence: salman.qureshi@geo.hu-berlin.de; Tel.: +49-152-1065-6043
}

Received: 9 July 2020; Accepted: 24 July 2020; Published: 31 July 2020

\begin{abstract}
Vacant, abandoned or unproductive land parcels, sometimes called "wastelands", offer opportunities to create new green spaces in cities. Such spaces may be utilized to add to the stock of urban nature, expand recreational green space, promote real estate or commercial development, or simply remain undefined. These various trajectories have significant implications for population health, ecosystem services and real estate values. However, they may also contribute to inequitable outcomes. Are disadvantaged communities, which may be paradoxically rich in wastelands, more advantaged when green space redevelopment occurs, or are they more at risk of green gentrification and associated displacement? To address this question, we first review some of the literature relative to wastelands, especially as they relate to processes of urban change such as depopulation, land use planning, regrowth and gentrification. We utilize historical redlining maps, the Detroit Master Plan and projected land use scenarios from the Detroit Future City (DFC) Strategic Framework Plan to identify areas of vulnerability or possibility within walking distance of the proposed Joe Louis Greenway (JLG). Finally, we consider how wastelands situated along the JLG may be reframed as flexible opportunity spaces, their potential leveraged to advance environmental justice, economic opportunity, and social equity, especially as the City of Detroit takes socioeconomic and racial equity as a key orienting principle-an alternative to green gentrification that we call green reparations.
\end{abstract}

Keywords: urban sustainability; cultural landscapes; urban greenspaces; urban ecology; urban regeneration

\section{Introduction}

What use are 'wastelands'? In Matthew Gandy's 2018 film, Natura Urbana: The Brachen of Berlin, plants, birds, and insects are shown to thrive on areas locally known as brachen, which residents came to value as "spaces of spontaneous nature". According to Lachmund, "redevelopment advocates employed aesthetic characterizations that framed the wastelands as signatures of urban disfigurement 
and decay" [1] (p. 164). Opponents of these redevelopment projects, on the other hand, argued that the wastelands represented valuable examples of ruderal ecology as well as social resources for surrounding populations. From their perspective, "redevelopment was anything but an innocent measure of urban renewal. It was essentially a destructive act, a sacrifice of Berlin's most extraordinary pieces of urban nature" [1] (p. 165). Kowarik's reframing of 'wastelands' as a unique form of natural resource-a vibrant presence, rather than an absence-was linked to campaigns for increased access to recreational spaces for inner-city populations and enabled the development of authentically wild urban park spaces that help define Berlin today $[2,3]$.

The challenges faced by Berlin in its era of abandonment echo in other places where redevelopment looms following decades of institutional neglect, for example, in post-communist Poland where 'wastelands' are saddled with pejorative connotations [4,5]. Berlin itself is now facing increasing development pressures that threaten to consume areas not formally preserved as park spaces. In his recent study of the Green Belt Berlin (GBB), Kowarik focuses on the combination of social, ecological and policy factors that contributed to the preservation of key sections of former wasteland as public green space [3]. Berlin's case is unique in many respects, but the question of whether land abandoned by markets should be preserved as urban nature, converted into parks, or developed into commercial real estate when markets return, confronts other cities seeking not only environmental but social sustainability following periods of abandonment.

In this paper, we consider the potential relationship between wastelands, greenways and gentrification in Detroit, Michigan, USA, a city that is currently experiencing tensions related to redevelopment of its abandoned spaces, in the context of a long history of racial injustice. We begin by discussing the indeterminacy of such spaces, contending that the language employed in the U.S. is deficient when it comes to reckoning with their multivalent characteristics. We share the concerns of Wolch, Byrne and Newell, concerning the paradoxical relationship between urban green space and issues of social equity [6]. We also take a cue from Nassauer and Raskin [7], who identify spaces of urban vacancy as a potential frontier of social and ecological research and design, and consider Kowarik's [3] examination of the Green Belt Berlin as a potential model for balancing social and ecological concerns. We consider the relationship between greenways and gentrification, referencing high profile examples such as New York's High Line, the Atlanta Belt Line, and Chicago's Bloomingdale Trail. We then turn to Detroit, using the planned Joe Louis Greenway (JLG) as a test case for greenways as opportunities to address social equity goals through expansion of beneficial green space in historically traumatized communities. We offer the concept of green reparations as an alternative to green gentrification: a trajectory that cities may pursue as they seek to curb market-driven displacement and preserve open and inclusive green spaces in proximity to transformational greenway developments. Our larger goal, presented in our conclusion, is to inform the work of planners, governments and local communities as they try to balance social, ecosystem, and economic demands in the implementation of greenway designs.

\section{Background: Making Space for Wastelands}

In much of the U.S. planning literature, areas that might be identified positively as brachen or 'fallow spaces' in Germany have no such corresponding designation. Instead, they are often viewed as an absence or negative influence, categorized simply as 'blight.' Mathey et al. use the term "brownfields" in their discussion of attitudes towards "spontaneous vegetation" in Leipzig and Dresden [8], but in the U.S., this term has a very specific legal definition and connotes industrial contamination. In Detroit, 'blight removal' has been a major focus of government, while the spaces left behind are largely viewed as blank spots to be filled with future development. According to the United States Environmental Protection Agency (U.S. EPA), "A brownfield is a property, the expansion, redevelopment, or reuse of which may be complicated by the presence or potential presence of a hazardous substance, pollutant, or contaminant" [9]. Mallach, for example, presents a policy case for utilizing vacant lands for planned long-term greening that enhances environmental sustainability and quality of life in areas depopulated 
by deindustrialization, especially in "legacy" cities of the so-called Rust Belt, such as Cleveland (Ohio), Detroit, Buffalo (New York), and others [10].

Likewise, using Roanoke, Virginia, as their study site, Kim, Miller and Nowak developed five different categories of vacant land: "post-industrial sites, derelict sites, unattended with vegetation sites, natural sites, and transportation-related sites" [11] (p. 144). The stated purpose of their analysis is to aid planners and designers in making decisions about uses of vacant land. Newman and Kim take a similar approach in Fort Worth, Texas, identifying "urban shrapnel" as "nonproductive space" (NPS), that is distributed throughout the body of the city as a potential resource for land use planners that may also be a drag on redevelopment efforts [12] (p. 14). They explain their concept of urban shrapnel using somewhat mechanistic terminology: It is a land use typology of the internal frontier. Urban shrapnel's frequently under-sized area, odd location, peculiar shape, and disconnected nature make it difficult to re-purpose, but it is still readily available for extemporaneous reuse (even temporarily).

While the term "extemporaneous reuse" implies informal activity, gentrification does not enter into the discussion in either of these articles, nor does trauma-both terms that Kowarik [3] employs in his discussion of the Green Belt Berlin (GBB). This is especially interesting given the use of terms such as "shrapnel" and "frontier" that connote both wounding and colonization.

Indeed, histories of harm and associated trauma related to deindustrialization, poverty, war, racial or class oppression may be invoked when these areas are redeveloped, especially if the benefits of that development are not distributed fairly. Conversions to green space that acknowledge and incorporate histories of dispossession and oppression may be more likely to engage surrounding residents and include those whose memories are tied to specific sites, as described by Kowarik [3], in relation to the decentralized and memorialized segments of the Berlin Wall. Reporting on developments in Atlanta [13] and Chicago [14], U.S.-based researchers have also found that a sense of community pride and ownership increased local support of greenways.

Bergin and Rupprecht approach the relationship between heritage landscapes and the traumas of the past by focusing on the Brighton seafront, an area directly implicated in the African slave trade [15]. Similarly, Stewart et al. described the community benefits of resident-led beautification of vacant lots in Chicago, but focused on how residents sought to change negative narratives and overturn stigmatized images of their communities [16]. Though they do not mention gentrification per se, they contend that resident-led programs may offset displacement if they include "provisions to ensure that the benefits of vacant lot re-purposing primarily go to long-term residents" [16] (p. 208). In their study of transformed industrial sites in Europe, Meier and Aytekin (2018) focus on the narratives of loss associated with places that once employed people or provided services to communities [17]. Pieck (2018) notes similar themes in her exploration of the now green borderland between the former East and West Germany: "In the case of the Green Belt, a landscape with a violent history, narratives are layered, with the ecological restoration project as just one more in a palimpsest of meaning. Whose voices are elevated in the creation of a storied wilderness and whose are buried, erased?" [18] (p. 2).

Green space conversion carries with it another potential risk, aside from erasing the past: it may actively contribute to the displacement of poor and aging residents. A rich emerging literature on green gentrification [19], ecological gentrification [20] and environmental gentrification [21,22] examine the interconnection between (presumably) well-intentioned efforts to produce environmental benefits and (perhaps) unintended outcomes such as increased home values, and accompanying displacement of poor, disabled, elderly or otherwise troublesome populations. Others have explored this dynamic in Vancouver [23] and Milwaukee [24], focusing on the convergence of neoliberal redevelopment priorities with environmental and health goals that may be favored by nonprofit funding agencies or nongovernmental organizations (NGOs). This line of reasoning also finds purchase in Detroit, as we shall see. 


\section{Methods: Connecting Wastelands, Greenways and Ecologies of Gentrification}

Cities consist of evolving patchworks of residential, commercial and green space, with that green space performing functions or providing services to both local inhabitants (human and non-human) and the larger city or region, even if these are not yet known or acknowledged. However, the social meanings and benefits attached to these green spaces may be quite dynamic and variable. According to Kowarik [25], "Wilderness is perceived in quite different ways, e.g., as a sphere of amorality, a sacred site or as a place of fear, of nature's self-reassertion, of escape from rules and restrictions, or of relief from stressful daily life". It is notable that "blight" is a word that rarely appears in German studies. Kowarik, for example, makes no mention of blight in his articles describing urban landscape types in Berlin [2,3,25]. Haase mentions blight once, in her discussion of land use in shrinking cities, but primarily in reference to former industrial sites or brownfields [26].

The ecological benefit of uncontrolled spaces is difficult to value in economic terms, and tends to be discounted, like non-human actors themselves. According to Crosby, "Weeds are the Red Cross of the plant world; they deal with ecological emergencies ... weeds, like skin transplants placed over broad areas of wounded and abraded flesh, aided in healing the raw wounds that the invaders tore in the earth" [27] (pp. 169, 170). In their study of plant life found on paved streets or "gray spaces" in a French city, Bonthoux et al. found that species diversity was higher in industrial or commercial areas, where herbicide use was less prevalent, and the desire to eliminate weed populations was less strong [28]. Research in Detroit has likewise found that bumble bee populations are healthier in these areas due to the presence of non-disturbed habitat $[29,30]$.

Nonetheless, weeds in urban settings are often equated to unruly populations and social problems that also needed to be controlled [31]. Historically, city planners have utilized green spaces to convey normative cultural and aesthetic values for the purpose of pacifying unruly urban populations. According to Loughran, "The history of urban parks is in large measure a history of planners' efforts to spatially mediate social problems" [32] (p. 3). The latest manifestations of this tendency are conveyed by terms such as "green infrastructure" and "ecosystem services" which imply that green spaces can be used to manage the environmental problems facing cities while also introducing ecological diversity. Beck, in discussing the high-profile High Line Park project in New York city, focuses on the use of the space for economic and political purposes; he discusses its ecology: "Before it became a celebrated public park, this abandoned rail line on the west side of Manhattan drew urban explorers onto its elevated docks, where an unexpected wilderness had emerged" [33] (p. 10). The designed park preserves some of these elements of wilderness, but within a managed framework. Beck describes the process of creating this semi-wild space within the crowded central city: "A total of \$152 million was spent on the first two sections' few slender acres, to upgrade the infrastructure and make it safe for visitors, to design and mix specialty soils and lift them by the bagful onto the platform, and to procure and plant the thousands of grasses, flowers and trees that evoke the spontaneous nature they replaced" [33] (p. 11).

Loughran uses New York City's high-profile High Line project as an example of a space "created as a means of luring tourists, wealthy white people, and the 'creative class' to downtown areas" [32] (p. 4). Prior to its redevelopment, the High Line, an elevated former industrial railway, abandoned and overgrown, was valued by some residents precisely because of its unruly aspects. Loughran portrays the High Line's later development as an almost archetypal example of "Neoliberal Public Space", which expresses "the relationships among citizens, the state, and other institutions of power" [32] (p. 51). In this view, the post-industrial wasteland space that previous mayoral administrations sought to dismantle became a key fulcrum point in the Bloomberg administration's hyper-gentrification of the Lower West Side of Manhattan.

For Beck, the same site represents ecological landscape design, a practice intended for "the growing number of places where there is no going back to the way things were"; the goal of which is to "apply our knowledge of nature to create high-performing landscapes in which our design goals and natural processes go hand in hand" [33] (p. 12). In his usage, "high performing" pertains not to economic 
outputs but to ecological processes: Ecological design is that which requires fewer resource inputs and is more able to "live through a catastrophe and recover" in a "world ruled by change and chance" [33] (p. 13). It is also interesting to note that in Beck's entire 216-page text, the words "gentrification" and "crime" do not make a single appearance. Likewise, in Beatley's book, Biophilic Cities, the High Line is mentioned briefly as an example of an innovative way of bringing nature back into a dense city where green space is in short supply [34].

Millington, in his discussion of the High Line project, considers the perspectives of both the project's designers and its critics in relation to the role of terrain vague, another term of art for brachen, or 'wastelands' [35]. According to Millington, many contemporary scholars view such "urban waste spaces as imaginative sites that disorder modernist urban imaginations through their implicit challenge to a fixed approach to landscape design" [35] (p. 2326). While he clearly sympathizes with those critics who see the High Line development as a commodification of urban nature in the service of gentrification, he also cautions against romanticizing wastelands as being "foundationally oppositional to the broader dynamics of capitalist urban politics" [35] (p. 2333). He shifts the focus from the design of the landscape to the exploitative political economy that drives the process. He writes, "The notion of a wilderness apart, an ecology that thrives in abandonment, is tempting: it offers the chance of escape from a socio-ecological future that becomes more apocalyptic by the minute" [35] (p. 2335). Likewise, Gandy identifies the tension between "wasteland aesthetics" and the design goals of both restoration ecology and urban redevelopment [36].

The balance of ecological and sociological dynamics in wasteland spaces takes on a new urgency if the potential for gentrification is considered [37] (p. 1). Greenways represent an emerging mechanism that may repurpose areas perceived as 'wastelands' and fueling gentrification. Often defined simply as linear parks, the very purpose of greenways is to connect places to each other. Therefore, their significance extends beyond the contents or design of the parks themselves. Greenways can tie scattered patches of green, some already defined as parks and others relegated to the wasteland category, into a new constellation of meaning and power. Areas of perceived vacancy within walking distance of these developments may be subject to new pressures while also offering new possibilities, as examples from other cities and regions demonstrate.

Residents of these communities may not see the value of spaces strongly associated with abandonment, crime and blight. In cases such as the High Line, the Belt Line, and the 303, access and enjoyment of redeveloped spaces may be much more inclusive-that is, appealing to far more people-than their more forbidding demeanor as wasteland spaces. At the same time, this broad popularity may result in displacement and economic exclusion promoted by market-driven development. As Detroit's investor class pushes to redevelop select segments of the city after years of racialized abandonment and neglect, one necessarily questions how these dynamics will play out, and with what implications for landscape design, for people, and for communities. When associated with greenways, these so-called 'wastelands' may quickly come to be perceived very differently, causing one ecology to make way for another.

Here, some guidance may be found in Berlin. Kowarik [3] looked at three dimensions of the GBB: city-wide planning concepts directing the GBB, conceptual principles realized in implementation of the GBB, and greenspace provision in less privileged neighborhoods (p. 13). For the first dimension, he utilized the city of Berlin's official Landscape Program as his main source; and for the second dimension, he considered how the GBB planning process implemented principles of cultural heritage, biodiversity conservation and social demands. For the last dimension, he employed three different GIS measures: population density, green space provision, and socioeconomic status, within a $1 \mathrm{~km}$ buffer zone around the GBB. In exploring the potential development trajectories of the JLG, we likewise consider several sets of overlapping factors, expressed in four different maps. First, we present the map of the proposed JLG route itself, as an idealized vision for a more equitable and sustainable city. Secondly, we discuss the traumatic history of racial segregation, with a map showing the JLG route superimposed on a historical map of racial redlining. The Detroit metropolitan region is highly uneven 
in terms of social vulnerability measures, and these spatial patterns directly reflect that redlining history. Thirdly, we compare maps showing Detroit's current land use master plan and published projections of land use fifty years in the future. We then utilize images of actual sites from a specific segment of the proposed JLG route to illustrate the variability of landscapes, which reflect the history of these neighborhoods, their challenges, and their possibilities. In addition to thematic maps, we also consider evidence from city zoning hearings and community engagement sessions that demonstrate these themes. Following this, we discuss the implications of our analytical framework for the design and implementation of the JLG.

\section{Results: Two Potential Trajectories}

In this section, we seek to ask some critical questions concerning potential social impacts related to the construction of the Joe Louis Greenway (JLG) in Detroit, aside from the presumed benefits of increased access to green space, recreational opportunities and enhanced ecosystem services. Instead, we consider the characteristics of surrounding communities, as well as the design process and planning goals of the city and its partners, such as nonprofit or private developers.

We hypothesize two potential trajectories in Detroit relative to the JLG: (1) green gentrification and (2) green reparations. In the green gentrification scenario, we predict that green space projects will result in more market-oriented development and more open space will move into private hands, rather than being dedicated to community or public use. Lees, Slater and Wyly define gentrification as "the transformation of a working-class or vacant area of the central city into more middle-class residential and/or commercial use" [38] (p. xv). Specific negative social impacts potentially caused by gentrification include residential displacement; exclusion; transformation of public, social and commercial space; polarization; and homogenization [39] (p. 90).

In the green reparations scenario, green space projects would be undertaken with a specific intent of achieving social equity. Their benefits would systematically target the very areas and populations most harmed by historic trauma, including racial segregation, economic disinvestment, institutional abandonment and environmental injustice [40]. As expressed in demands for a "Green New Deal for Detroit", distributed in advance of the Democratic Presidential Debates in Detroit in July of 2019, any new development in the city would seek to "address historic harm and prevent present and ongoing industrial harm", with a special focus on "frontline communities" that "have had to deal with the impact of industrial plants, toxic waste sites, incinerators and pollution within close proximity to their homes" [41]. While this is certainly an aspirational agenda and an uphill political battle, its goals overlap with Detroit Design Core's stated commitment to "inclusive design", which is "rooted in a belief that inclusive design practices can shape systems, processes, places and products to generate sustainable and equitable results that benefit all" [42].The JLG, named after a legendary AfricanAmerican athlete who lived in Detroit during the era of legal segregation, provides a potential test case for this vision of inclusive design, and a potential form of green reparations (Figure 1). It will traverse areas traumatized by the city's history and the upheavals that occurred along the way, including the racial redlining of the 1930s (see Figure 2). Detailed redlining maps of Detroit, including the data sheets explaining why each area was rated as it was, may be found at "Mapping Inequality: Redlining in New Deal America" [43] and contain the block-by-block battles over housing integration that took place throughout the 1940s and 1950s; the construction of freeway ramps and other urban renewal projects that plowed through Black and low-income communities, and separated them from more affluent areas; the rebellion of 1967, and the subsequent stigmatization, disinvestment and abandonment of once thriving communities. These are the very communities who fear that they may be left behind in the current phase of redevelopment. It is therefore quite fitting to identify racial equity and economic inclusion as central goals of this project. 
As Heynen has written, "Much of the research dealing with racialized and colonial Urban Political Ecology proceeds by detailing and describing the ongoing aftermath and resulting unevenness of the circumstances that produced the uneven urban natures in question" [44] (p. 841). In the case of Detroit, the abundance of visible green space inside the city directly reflects its long history of redlining, disinvestment and white flight. In a green reparations scenario, we propose that this green and open space, or some significant portion of it, would be preserved for public, non-market directed use, with benefits of that development specifically directed at those most disadvantaged by past policy and practices. Likewise, those areas most burdened by histories of harm would realize the greatest gains in terms of green space access and its benefits, with policies implemented specifically to allow people to stay and realize benefits in place. For this purpose, we propose an analytical framework to highlight areas that are most at risk, but also potentially have the most to gain from the paradoxical wealth of 'wastelands' or transitional green spaces bequeathed to them by this history.

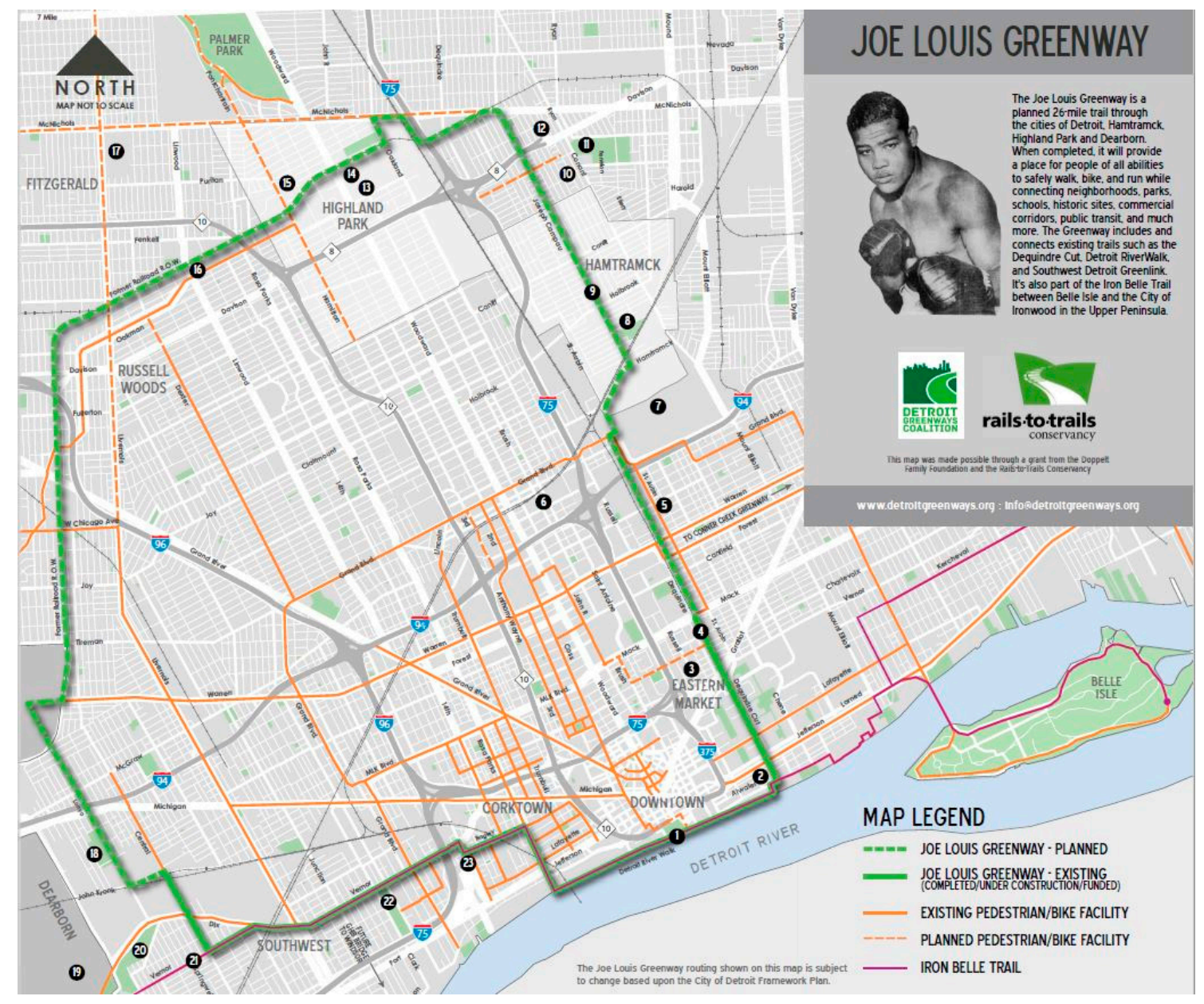

Figure 1. The projected route of the Joe Louis Greenway (Image courtesy of the Detroit Greenways Coalition, used with permission). 


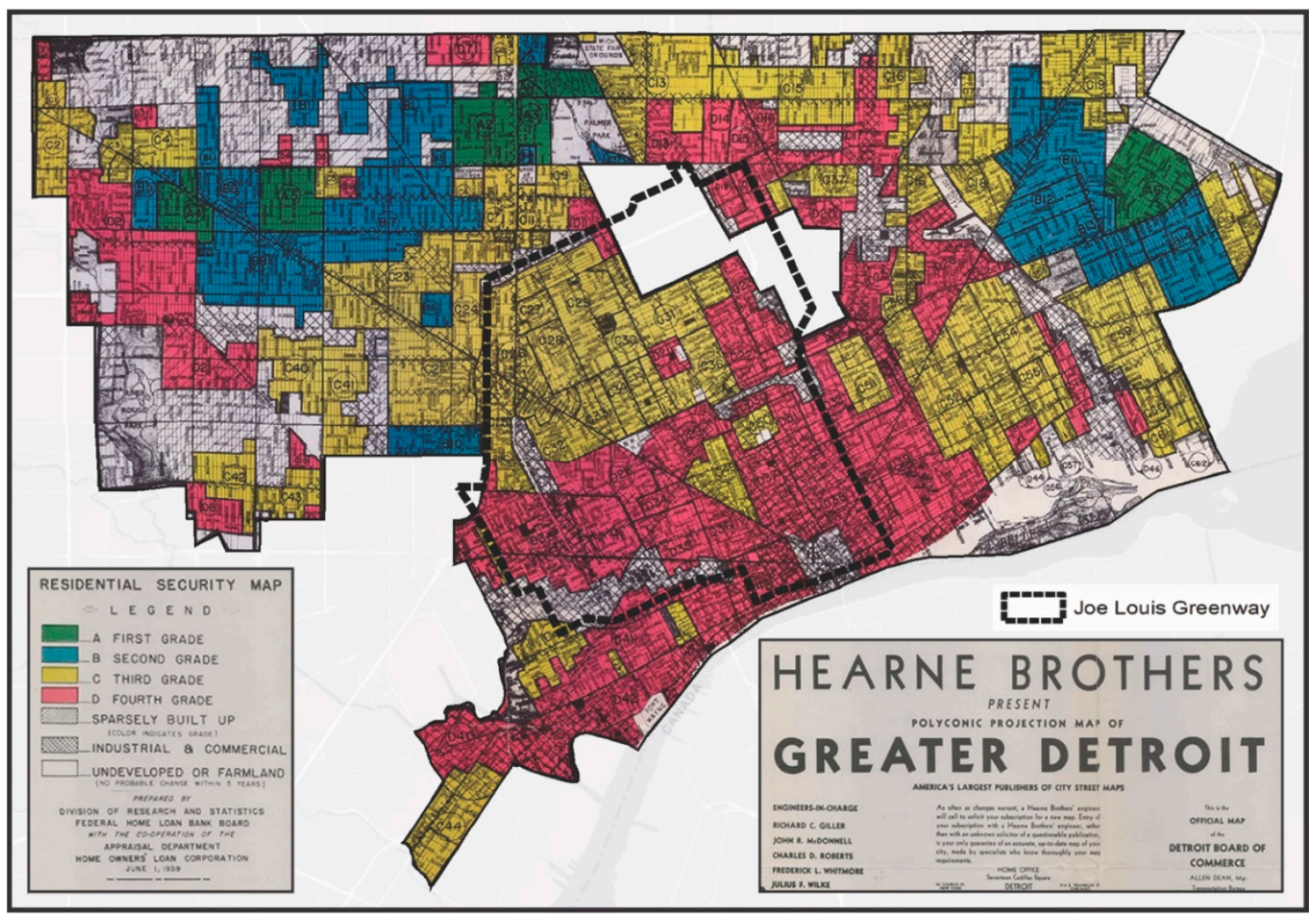

Figure 2. Historic redlined areas and the route of the Joe Louis Greenway. Areas coded red and yellow were identified as high-risk areas for investment and systematically denied residential loans.

The Social Vulnerability Index (SoVI), used by Meerow and Newell in their examination of green infrastructure projects in Detroit [45], accounts for racial demographics, poverty levels, per capita income, rent, mobility, housing characteristics, family structure, language barriers, employment, and others. It mirrors an index of gentrification developed by researchers in Chicago, which showed that higher levels of income and owner occupation were strongly correlated with gentrification trends that led to communities becoming more expensive and exclusive [46]. Almost all of the communities touched by the JLG demonstrate high degrees of vulnerability, according to the first index, which would place them at lower immediate risk of gentrification. However, concentrated redevelopment and investment, while might normally be perceived as a benefit rather than a detriment to such disadvantaged neighborhoods, could also be more likely to displace vulnerable populations who are less equipped to organize, mobilize, channel or resist investment or planning decisions that are imposed "from above" by the "powers that be". To better predict likely future trajectories, we must consider the plans and priorities articulated by the city government and other stakeholders and decision-makers.

The Detroit Planning Department's Master Plan, completed in 2009 and updated periodically thereafter, provides the best sense of how the city government currently views these areas. In addition, we utilize the aforementioned DFC as a source of insight into the potential development trajectories of different sections of the city intersected by the JLG. Of course, the future is impossible to predict, but Detroit Future City (DFC) attempts to lay out a set of directions. For our purposes, the most suggestive elements of DFC are included in its '50-year Land Use Scenario' map, which divides the city into a system of color-coded zones.

In comparing the two maps (Figure 3), we can see that most of the DFC categories reflect traditional zoning or variations on it (Green Residential and Green Mixed-Rise), but several of them stand out as experimental or even aspirational categories, including "Innovation Productive", "Innovation Ecological" and "Live+Make". The JLG's proposed route intersects with several of these 
experimental zones: Green Residential and Mixed-Rise in the SE section, Innovation Productive in the East, Innovation Ecological in the NE, and a mixture of Green Residential and Innovation Ecological with traditional Medium Density Residential in the NW and W sections, while the SW is dominated by General Industrial and Medium Density Residential, reflecting its history as industrial working-class neighborhoods. In the redlining maps of the 1930s (Figure 2), these adjoining residential areas were all rated either 3rd Grade (Yellow) or 4th Grade (Red) on a scale from 1-4. The Red designation was meant to signify that the area was "Hazardous" which was a status usually associated with concentrations of poor, ethnic, working-class and Black populations, as well as industrial properties. For example, the sheet for area D15 contained the following description: "High foreclosure and turnover due to removal of Ford Plant from Highland Park. Negro and alien area. 40\% developed. 4th grade area".
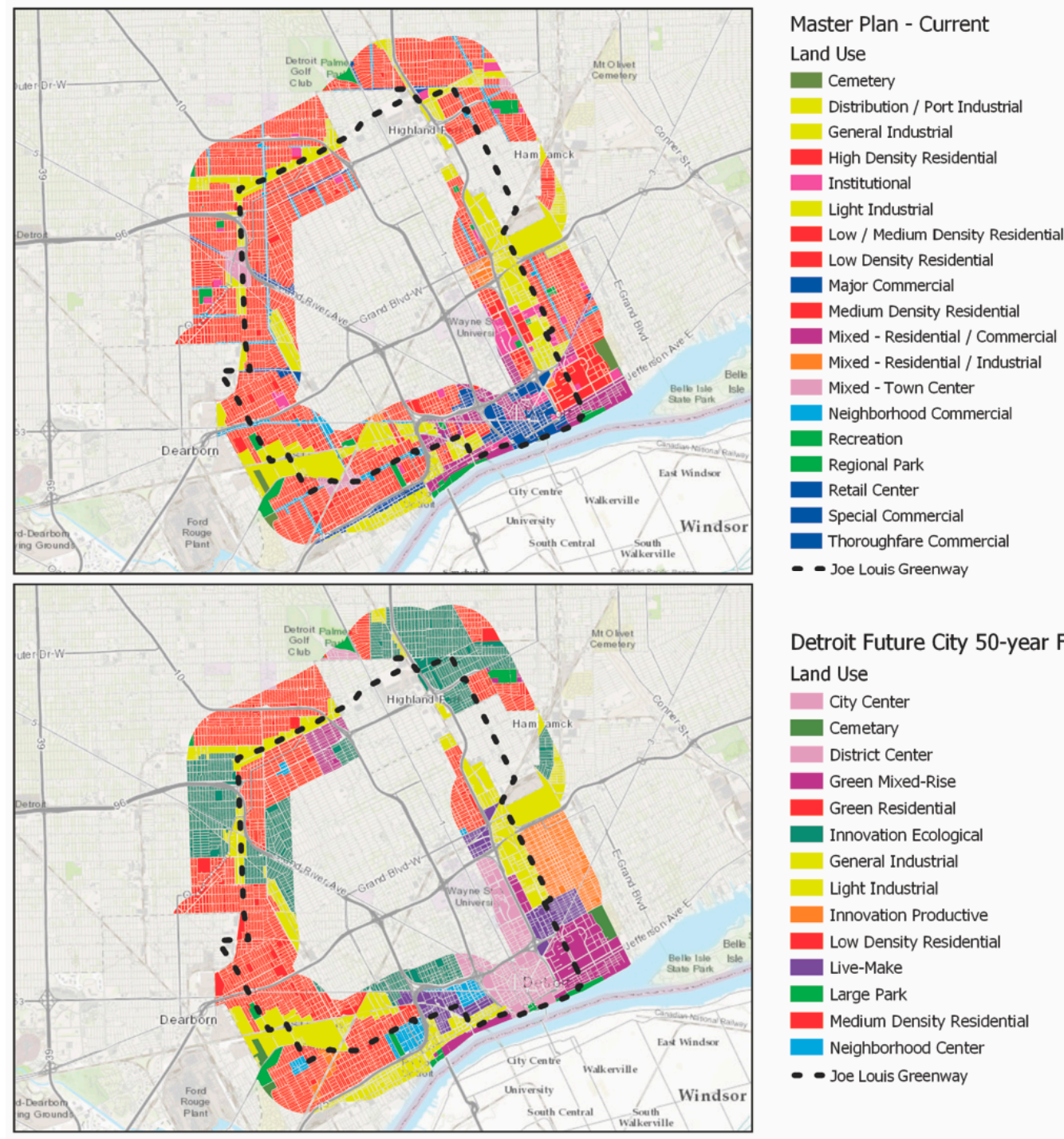

Detroit Future City 50-year Framework Land Use

City Center

Cemetary

District Center

Green Mixed-Rise

Green Residential

Innovation Ecological

General Industrial

Light Industrial

Innovation Productive

Low Density Residential

Live-Make

Large Park

Medium Density Residential

Neighborhood Center

- - Joe Louis Greenway

Figure 3. Detroit Master Plan and Detroit Future City 50-year Framework Projection, with Joe Louis Greenway. In the bottom map, the blue-green areas, currently zoned low-to-medium density residential have been identified as sites of potential "Ecological Innovation".

On-the-ground investigation reveals that the northern section of this route traverses a quite varied terrain, characterized by complex combinations of commercial, industrial, and residential residue as well as an abundance of plant life and evidence of informal human activity, including dumping and graffiti. All of the images shown in Figure 4 depict areas within the "Innovation Ecological" zones of the DFC 50-year Framework for Land Use. Though not defined formally as green space, the open 
fields and abandoned rail lines that the greenway will traverse are actively utilized by both human and non-human actors. How the planning and design of the greenway engages and includes these other actors will be crucial to its development trajectory. The figure below shows some of the landscape varieties currently existing along one small stretch of the proposed greenway. The current ecologies of these sites, inclusive of social, human and natural histories and activities, may be inevitably altered by the redevelopment that the greenway promises. However, these ecologies may also shape that development in important ways.
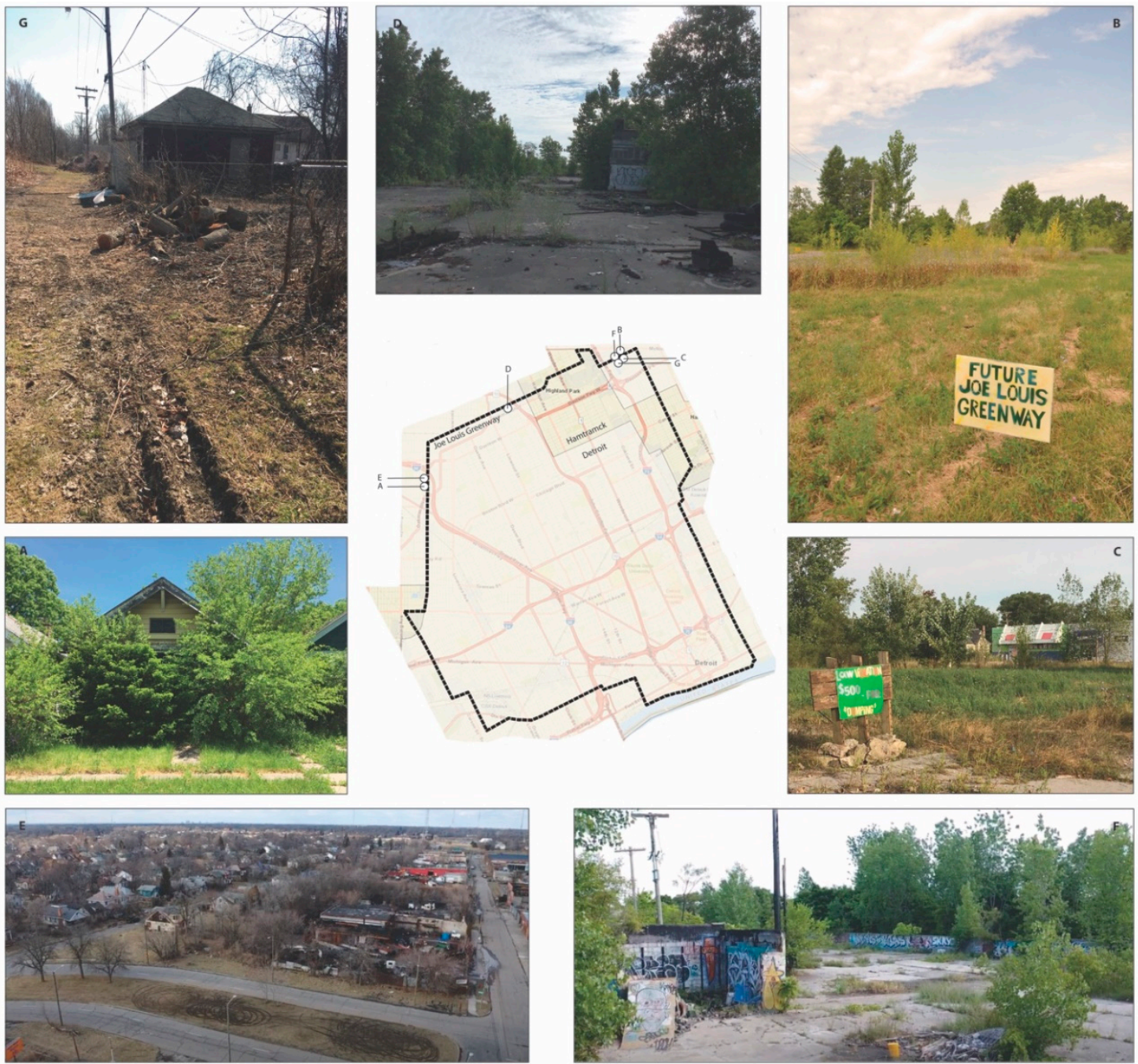

Figure 4. Visual evidence of landscape variation along the proposed northern route of the Joe Louis Greenway, showing urban spontaneous vegetation and structural residue of commercial, residential and industrial development.

At a city zoning meeting in December 2018, one of the residents described their neighborhood this way:

"We are one of the poorest districts in the city, a lot of blight, a lot of abandoned property. In terms of development, if a developer is looking for land to develop, that's a good problem to have. They [owners of proposed junkyard] seem to think it's okay, it's a poor community, it's blighted. Something like a scrap yard will take the value down more."

These residents were more worried about the addition of more junkyards in their area than they were about luxury condominiums or boutique shops, but they were also insistent on the potential for a 
more promising future. Another resident attending the same zoning meeting proudly proclaimed the intention of community members to guide their own future development:

"We have a rich history. We shouldn't go backward, we want to go forward. We want the Zoning Board to know what we are doing, to plan our community. I don't see this district as the poorest; I see [it] as a template."

This statement signals the presence of a community motivated to develop their own community, in a way that benefits the committed, long-term residents, as well as also providing a model for others.

At community meetings for the JLG convened throughout 2019, we saw similar hopes and fears expressed. City planners engaged residents in discussions about the potential activation of spaces currently defined as vacant or abandoned. Prominent assets identified by residents included: historic buildings, parks, universities, churches, cemeteries; commercial corridors and districts; proximity to other cities or neighborhoods; cultural diversity and density; redevelopment opportunities for vacant/abandoned land; and alleyways that could be activated as connectors to and from the JLG. Priorities for the JLG identified by residents were: equitable growth; environmental sustainability; community identity; public safety; community involvement in place-making; and economic development of local/black businesses. The sessions themselves were set up to be fun and cooperative with an engaged and energetic facilitator, who stated simply and clearly that: "The Joe Louis Greenway is a game changer, changing Detroit for generations to come".

The design team sat at one end of the room, while each table was designated as a city district. This was intended to produce optimal feedback from those who know their communities best-the ones that lived there. We (first and fourth author) participated in these table discussions, sitting in two different "neighborhoods". Discussion of the potential for the JLG to develop economic opportunities for housing and commerce competed with residents' concerns about land grabs, exploitative landlords, opportunistic real estate speculation, and fears of gentrification. While these concerns may be beyond the powers of the JLG design team to directly control, the session brought opportunities for meaningful suggestions. A resident spoke of allowing commercial use in homes along the JLG to capitalize on economic activities within their community. One woman described a beneficial chain of possibilities: "We need to have equitable development but also environmental sustainability, [this] has potential to build new housing, housing helps address the blight, then businesses will come, then once the businesses come, there will be jobs, and once we have jobs, then we will focus on people being healthy and fit". Another resident spoke of homebuyer grants to be leveraged as a community benefits accommodation, giving those who live near the JLG the chance to own their homes to offset potential gentrifying pressures when property values rose. Others offered more ideas for the JLG team to consider, such as the importance of access and inclusion for disabled bodies, the removal and recycling of dead plants and waste, and the creation of educational-recreational nodes throughout the JLG for interactive engagement.

\section{Discussion: Detroit's Contested Futures}

In cities where transitional spaces, otherwise known as wastelands, exist in abundance, due to natural, economic or other man-made disasters such as wars, deindustrialization or racialized abandonment, it is hard to deny their influence on the surrounding social and natural environment [7]. If order consists of elements that one expects to see together in certain places, then Detroit, like Berlin, consistently disrupts that expectation with its broad and shifting tableaux of surprising combinations of natural and human elements [47]. Hoalst-Pullen, Patterson, and Gatrell refer to this as Detroit's "green paradox" [48] (p. 430). Due to the levels of housing foreclosure, arson, abandonment and outmigration, the city continually sprouts weeds (adventive plants) and graffiti (marginal art), which are visible indicators of unregulated and vibrant natural and human activity. Such areas may seem distantly removed from the market pressures that contribute to gentrification, but new alignments created by greenway development may alter both the metaphorical and actual ecology. 
The introduction of a major landscape feature such as a greenway might have a ripple effect on surrounding communities, raising the price of land and shifting the profile of residents and businesses. The Atlanta Belt Line provides one striking example of a greenway project that has quickly transformed vacant properties and distorted real estate markets in surrounding neighborhoods, quickly driving displacement [49]. According to Rigolon and Nemeth, this has also occurred in Chicago in the vicinity of the 303, also known as the Bloomingdale Trail, a greenway project that connected working-class communities on the northwest side of the city by transforming an old abandoned rail line into an accessible multi-use trail [50]. Like Kowarik, they focus on the planning process in evaluating the outcomes of the trail development, and find that the expansion in green space access brought unanticipated consequences in terms of market-driven displacement as the 303's popularity surged.

In Leipzig, Germany, another city that suffered significant population loss following World War II, a similar process is underway [51]. Leipzig's plan to create a Green Ring of connected trails and green spaces in a city afflicted by depopulation and abandonment, with ample amounts of transitional green space, offers another case study of the relationship between wastelands, gentrification and social benefit [52]. The example of the Lene-Voigt Park shows that the reuse of an industrial brownfield into a city park, even with popular support and sensitive design, may trigger residential change and renovation, resulting in rising housing costs and exclusionary displacement [53]. On the other hand, Hillbrandt's [54] work on allotment gardens in Berlin and Bendt et al.'s 2013 [55] work on public-access community gardens (PAC) demonstrate how local actors on the ground may mediate or modify state policies, partly filling gaps of missing state policies, transforming the use of land through their own actions upon it-for example, by means of co-created associations (Trägerverein) or social enterprises $(\mathrm{GmbH})$ as forms of interim permitted uses [56]. In both East Berlin and Leipzig, two formerly shrinking cities, space appropriation in the form of community gardens has led to early and spontaneous forms of void space implementations, shaping and making the city [57]. Kinder has described a similar informal process of land use appropriation in Detroit [58].

The formal development of the Joe Louis Greenway (JLG) project itself represents the outcome of years of informal use and advocacy on the part of cyclists and others invested in a greener, less auto-dependent city, for a system of interconnected greenways that will connect the whole city [59]. According to the Detroit Greenways Coalition website, the JLG will be a unifying project for the city:

When completed, it will provide a place for people of all abilities to safely walk, bike, and run while connecting neighborhoods, parks, schools, jobs, historic sites, commercial corridors and public transit [60].

The Dequindre Cut Greenway (DCG) was one of the first segments of greenway to be completed in Detroit. A documentary film entitled "A City to Yourself", shot in the mid-2000s by Nicole MacDonald, shows scenes of the DCG when it was an abandoned below-surface rail line inhabited by homeless people and wild dogs, just as greenway plans were beginning. The film concluded with the sentence, "We hope for better things; they shall rise from the grasses", which is a play on the actual Detroit city slogan: "We hope for better things. It shall rise from the ashes" [61].

Today's DCG might be seen as a fulfilment of the abovementioned prophecy as it retains elements from its industrial origins and its wilder days, but it is, in other respects, unrecognizable, a well-mowed and well-paved strip of gray and green that is designed to be inviting to everyone except the unruly elements who utilized it before. Detroit, as a member of the UNESCO City of Design network, has adopted "inclusive design" as its central value, and the Detroit Future City Strategic Framework Plan also embraces principles of "inclusion, community and the development of data-driven strategies" [62]. Of course, the future is impossible to predict, but Detroit Future City (DFC) attempts to lay out a set of directions. Beginning as the Detroit Works Project under former Mayor Dave Bing, in the midst of the late 2000s financial crisis, DFC "articulates a compelling vision of a smaller, greener Detroit" [63] (p. 272).

As the city emerged from municipal bankruptcy in 2014, DFC was often presented as the guiding vision for both city planners and nonprofit foundations, which play an outsized role in Detroit due to 
the public sector's diminished capacity. The DFC has been assailed as a model of neoliberal urbanism driven by austerity politics [64], but whatever one concludes concerning its economic and political motivations, the DCG represents the crystallization of its vision, fusing market-oriented development with social and environmental goals of expanding access to green space and enhancing ecosystem services $[65,66]$. The proposed multiphase development of the JLG will presumably build off the perceived success of the DCG, which itself partially replicates the formula of the High Line and other such well-known projects. It therefore makes sense to ask critical questions concerning the JLG design process as it progresses, based on examples from other cities where greenways have been implemented. The time is exactly right for Detroit to have this discussion.

\section{Conclusions: "Just Greening" as a Critical Design Challenge}

At a community engagement session for the JLG held in January 2019, two different groups of potential planners engaged the audience. A representative from the City of Detroit stated that this was a major planning project, and that their goal was "to figure out everything we could about the JLG", to understand "how neighborhood residents would inject their own sense of identity into the greenway". She said, "We really wanted to open up the whole process and make it public. To make everyone feel like it is their own greenway and they are part of the project". One of the design team members stated that she saw "the greenway as a catalyst not just for growth, but for inclusive growth". These initial meetings touched on a range of concerns, from housing affordability and public safety to environmental sustainability. However, as the old saying goes, the devil is in the details, and Detroiters had been burned by those devils before. Silverman et al. (2019) have described such citizen participation efforts as an "empty ritual" [67]. Both planners and residents hope this process will produce results that genuinely benefit Detroit's left-behind neighborhoods.

In relation to the GBB, Kowarik discusses both the landscape design and the planning process that contributed to that linear park's final (though still evolving) form, and how it both reflected and impacted the surrounding ecology [3]. He contends that a distinctive combination of planning principles, design processes, and political coalitions helped to achieve a socially beneficial result. As Meerow and Newell have demonstrated in relation to Detroit's planned green infrastructure investments, there is often a mismatch between the location of green projects and the greatest needs in terms of access to green space [44,68]. Wolch, Byrne and Newell have effectively outlined the challenges facing cities that seek to confront legacies of environmental injustice through provision of new green space, only to produce the paradox of green or ecological gentrification, which drives displacement of the very populations most in need of the benefits offered [6].

Ecologically, the choice of remaking weedy wastelands into well-manicured lawns or managed gardens, as was done with the High Line and DCG, raises serious questions in terms of ecosystem service provision, species diversity, high-energy input costs such as mowing and fertilizers, and unnecessary groundwater runoff in a time of climate change [69]. Riley et al. [37] maintain that urban spontaneous vegetation offers an undervalued resource for shrinking cities, and Rupprecht and Byrne have proposed that some informal green spaces might be preserved as deliberate anti-gentrification buffers, providing green space benefits without feeding into markets that drive gentrification and displacement [70]. The implementation of a "wastelands toolkit" such as that described by Nejman et al. in Warsaw, adapted to the Detroit context, might be useful in this regard. They recommend "a combination of bottom-up and grassroots processes of space creation, supported by the local municipality", incorporating the diverse users and stakeholders of the space into its eventual design [4] (p. 51). The availability of applicable models for utilizing so-called "wastelands" as beneficial landscapes, drawn from cities around the world, may result in more sustainable and diverse urban spaces in Detroit. For example, Foster and Newell have documented the unofficial footpath or "desire lines" that might be creatively considered as capillary systems feeding into arterial greenways [71]. The oft-noted visual beauty of Detroit's lush open landscapes might be retained while simultaneously addressing concerns about security, blight and economic opportunity. 
"Just greening", viewed as a process rather than an outcome, would deliberately incorporate the social dynamics of conflict and discussions of power and inequality that emerged in community meetings into the halcyon visions of landscape architects $[6,21,22,72]$. Specific questions for planners and designers may include: How can activation of neglected alleyways and vacant lots in urban communities play a key role in the economic redevelopment of each neighborhood while also contributing to beneficial green space access and enhancing ecosystem services? How can local green space projects of different types and scales leverage the benefits of government greenway investment to amplify both environmental and health benefits? Is eco-tourism a viable option for post-industrial neighborhoods that engage in alley activation and lot conversion? Most importantly, how can early engagement of designers and government officials with communities help to secure the benefits of these enhancements for residents who need them most? [73]. If green space is viewed as a form of environmental justice, as opposed to a mere lifestyle amenity, the design process takes on a whole different meaning. Ecological design principles, based on working in partnership with both nature and community, require the consideration of social as well as environmental criteria in creating truly restorative urban spaces $[74,75]$.

In proposing the hypothetical trajectories of green gentrification and green reparations, we recognize that a more likely real-world outcome may be some hybrid combination of the two approaches. Here, we predict that private-public partnerships, driven by nonprofit foundations, will seek to accommodate both the broader public and market-oriented entrepreneurs, and that governmental actors and community-based organizations may play a key role in constraining market forces or redirecting them to optimize community benefit. As the design process moves forward, sociological and geographic research methods may be utilized to show the stakes in this game-who stands to benefit and who is most vulnerable. If local constituencies are organized and equipped with such information early enough to shape design interventions in a meaningful way, the constellation of power introduced by the JLG may be leveraged to uniquely benefit some of the areas and populations most traumatized by Detroit's segregationist design history.

Author Contributions: Conceptualization, P.D., S.Q. and D.H.; methodology, P.D., S.Q. and D.H.; software, A.S., and J.N.; validation, P.D., J.N. and J.R.; formal analysis, P.D., A.S. and J.R.; investigation, P.D., A.S. and J.R.; resources, P.D. and S.Q.; data curation, P.D., A.S. and J.R.; writing-original draft preparation, P.D.; writing-review and editing, P.D., S.Q., D.H., J.N. and J.R.; visualization, P.D. and A.S.; supervision, P.D. and S.Q.; project administration, P.D. and S.Q.; funding acquisition, P.D. and S.Q. All authors have read and agreed to the published version of the manuscript.

Funding: This research was made possible by funding from the University of Michigan and Humboldt University of Berlin's Collaboration on Applications of Cooperative Research in the Social Sciences.

Acknowledgments: Thanks to Bilal Qureshi for handling the formatting of manuscript and figures. We acknowledge support by the German Research Foundation (DFG) and the Open Access Publication Fund of Humboldt-Universität zu Berlin.

Conflicts of Interest: The authors declare no conflict of interest.

\section{References}

1. Lachmund, J. Greening Berlin; MIT Press: Cambridge, MA, USA, 2013.

2. Kowarik, I. Cities and wilderness: A new perspective. Int. J. Wilderness 2013, 19, 32-36.

3. Kowarik, I. The "Green Belt Berlin": Establishing a greenway where the Berlin Wall once stood by integrating ecological, social and cultural approaches. Landsc. Urban Plan. 2019, 184, 12-22. [CrossRef]

4. Nejman, R.; Łepkowski, M.; Wilczyńska, A.; Gawryszewska, B.J. Theright to wild. Green urban wasteland in the context of urban planning. Urban Dev. Issues 2018, 59, 43-53. [CrossRef]

5. Gawryszewska, B.J.; Wilczynska, A.; Lepkowski, M.; Nejman, R.; Cziszewska, M. The recreational potential for wastelands as well as users' preferences for wasteland aesthetics: Case study of Warsaw, Poland. In Proceedings of the VI International Conference on Science and Technology (INFRAEKO 2018), Krakow, Poland, 7-8 June 2018; pp. 1-8. 
6. Wolch, J.R.; Byrne, J.; Newell, J.P. Urban green space, public health, and environmental justice: The challenge of making cities 'just green enough'. Landsc. Urban Plan. 2014, 125, 234-244. [CrossRef]

7. Nassauer, J.I.; Raskin, J. Urban vacancy and land use legacies: A frontier for urban ecological research, design and planning. Landsc. Urban Plan. 2014, 125, 245-253. [CrossRef]

8. Mathey, J.; Arndt, T.; Banse, J.; Rink, D. Public perception of spontaneous vegetation on brownfields in urban areas-Results from surveys in Dresden and Leipzig (Germany). Urban For. Urban Green. 2018, 29, 384-392. [CrossRef]

9. Overview of EPA's Brownfields Program. Available online: https://www.epa.gov/brownfields/overviewepas-brownfields-program (accessed on 29 July 2020).

10. Violet, I. Despite Demolition Efforts, Blight Spreads Undetected throughout Detroit's Neighborhoods. Available online: https://www.metrotimes.com/detroit/despite-demolition-effort-blight-spreads-undetectedthroughout-detroits-neighborhoods/Content?oid=17692371 (accessed on 29 July 2020).

11. Kim, G.; Miller, P.A.; Nowak, D.J. Urban vacant land typology: A tool for managing urban vacant land. Sustain. Cities Soc. 2018, 36, 144-156. [CrossRef]

12. Newman, G.; Kim, B. Urban shrapnel: Spatial distribution of nonproductive space. Landsc. Res. 2017, 42, 699-715. [CrossRef]

13. Palardy, N.P.; Bynum, B.B.; Gaither, C.J. Resident support for urban greenways across diverse neighborhoods: Two Atlanta BeltLine segments. Landsc. Urban Plan. 2018, 180, 223-233. [CrossRef]

14. Fernandez, M.; Harris, B.; Becerra, M. Examining the complexities of increasing park access in two LatinX neighborhoods. Local Environ. 2019, 24, 1136-1155. [CrossRef]

15. Bergin, C.; Rupprecht, A. Reparative histories: Tracing narratives of black resistance and white entitlement. Race Class 2018, 60, 22-37. [CrossRef]

16. Stewart, W.P.; Gobster, P.H.; Rigolon, A.; Strauser, J.; Williams, D.A.; van Riper, C.J. Resident-led beautification of vacant lots that connects place to community. Landsc. Urban Plan. 2019, 185, 200-209. [CrossRef]

17. Meier, L.; Aytekin, E.A. Transformed landscapes and a transnational identity of class: Narratives on (post-) industrial landscapes in Europe. Int. Sociol. 2019, 34, 99-116. [CrossRef]

18. Pieck, S.K. What stories should a 'National Nature Monument' tell? Lessons from the German green belt. Cult. Geogr. 2018, 26, 195-210. [CrossRef]

19. Gould, K.; Lewis, T. Green Gentrification: Urban Sustainability and the Struggle for Environmental Justice; Taylor and Francis: New York, NY, USA, 2016.

20. Dooling, S. Ecological Gentrification: A Research Agenda Exploring Justice in the City. Int. J. Urban Reg. Res. 2009, 33, 621-639. [CrossRef]

21. Curran, W.; Hamilton, T. Just green enough: Contesting environmental gentrification in Greenpoint, Brooklyn. Local Environ. 2012, 17, 1027-1042. [CrossRef]

22. Curran, W.; Hamilton, T. Just Green Enough: Urban Development and Environmental Gentrification; Routledge: London, UK, 2017.

23. Quastel, N. Political Ecologies of Gentrification. Urban Geogr. 2009, 30, 694-725. [CrossRef]

24. Pettygrove, M.; Ghose, R. From 'Rust Belt' to 'Fresh Coast': Remaking the City through Food Justice and Urban Agriculture. Ann. Am. Assoc. Geogr. 2018. [CrossRef]

25. Kowarik, I. Urban wilderness: Supply, demand and access. Urban For. Urban Green. 2017, $29,336-347$. [CrossRef]

26. Haase, D. Urban Ecology of Shrinking Cities: An Unrecognized Opportunity? Nat. Cult. 2008, 3, 1-8. [CrossRef]

27. Crosby, A.W. Ecological Imperialism: The Biological Expansion of Europe; Cambridge University Press: Cambridge, UK, 1986; pp. 900-1900.

28. Bonthoux, S.; Voisin, L.; Bouché-Pillon, S. Chollet, S. More than weeds: Spontaneous vegetation in streets as a neglected element of urban biodiversity. Landsc. Urban Plan. 2019, 185, 163-172. [CrossRef]

29. Glaum, P.; Simao, M.; Vaidya, C.; Fitch, G.; Iulinao, B. Big city Bombus: Using natural history and land-use history to find significant environmental drivers in bumble-bee declines in urban development. R. Soc. Open Sci. 2017, 4, 170156. [CrossRef] [PubMed]

30. Offord, C. Bees Live the City Life in Detroit. In: The Scientist. Available online: https://www.the-scientist. com/notebook/bees-live-the-city-life-in-detroit-30234 (accessed on 10 July 2018). 
31. Falck, Z. Weeds: An Environmental History of Metropolitan America; University of Pittsburgh Press: Pittsburgh, PA, USA, 2010.

32. Loughran, K. Parks for Profit: The High Line, Growth Machines, and the Uneven Development of Urban Public Spaces. City Community 2014, 13, 49-68. [CrossRef]

33. Beck, T. Principles of Ecological Landscape Design; Island Press: Washington, DC, USA, 2013.

34. Beatley, T. Biophilic Cities: Integrating Nature into Urban Design and Planning; Island Press: Washington, DC, USA, 2011.

35. Millington, N. From Urban Scar to 'park in the sky': Terrain Vague, Urban Design, and the Remaking of New York City's High Line Park. Environ. Plan. A 2015, 47, 2324-2338. [CrossRef]

36. Gandy, M. Unintentional landscapes. Landsc. Res. 2016, 41, 433-440. [CrossRef]

37. Riley, C.B.; Perry, K.L.; Ard, K.; Gardiner, M.M. Asset or Liability? Ecological and Sociological Tradeoffs of Spontaneous Urban Vegetation on Vacant Land in Shrinking Cities. Sustainability 2018, 10, 2139. [CrossRef]

38. Lees, L.; Slater, T.; Wyly, E. Gentrification; Routledge: London, UK, 2008.

39. Kohn, M. The Death and Life of the Urban Commonwealth; Oxford University Press: New York, NY, USA, 2016.

40. Draus, P.; Haase, D.; Napieralski, J.; Roddy, J.; Qureshi, S. Wounds, ghosts and gardens: Historical trauma and green reparations in Berlin and Detroit. Cities 2019, 93, 153-163. [CrossRef]

41. Payne, L. Protesters Demand Green New Deal ahead of Detroit Presidential Debate. Available online: https://www.detroitnews.com/story/news/2019/07/30/protesters-demand-green-new-deal-aheaddetroit-debate/1872132001/ (accessed on 16 August 2019).

42. Sherry, W. Design Core Detroit Competition to Recognize 'Inclusive Design'. Available online: https://www.crainsdetroit.com/article/20180509/news/660281/design-core-detroit-competition-torecognize-inclusive-design (accessed on 16 August 2019).

43. Mapping Inequality. Available online: https://dsl.richmond.edu/panorama/redlining/\#loc=14/42.4180/-83. 0901\&opacity $=0.8 \&$ sort $=71 \&$ city $=$ detroit - mi\&area $=D 13 \&$ adimage $=3 / 75 /-120$ (accessed on 29 July 2020).

44. Heynen, N. Urban political ecology II: The abolitionist century. Prog. Hum. Geogr. 2016, 40, 839-845. [CrossRef]

45. Meerow, S.; Newell, J. Spatial planning for multifunctional green infrastructure: Growing resilience in Detroit. Landsc. Urban Plan. 2017, 159, 62-75. [CrossRef]

46. Voorhees Center for Neighborhood and Community Improvement (2014). The Socioeconomic Change of Chicago's Community Areas (1970-2010). Available online: https://voorheescenter.red.uic.edu/wp-content/ uploads/sites/122/2017/10/Voorhees-Center-Gentrification-Index-Oct-14.pdf (accessed on 8 May 2019).

47. Lossau, J.; Winter, K. The Social Construction of City Nature: Exploring Temporary Uses of Open Green Space in Berlin. In Perspectives in Urban Ecology; Endlicher, W., Ed.; Springer: Berlin, Germany, 2011; pp. 333-345.

48. Hoalst-Pullen, N.; Patterson, M.W.; Gatrell, J. Empty spaces: Neighbourhood change and the greening of Detroit, 1975-2005. Geocarto Int. 2011, 26, 417-434. [CrossRef]

49. Immergluck, D.; Balan, T. Sustainable for whom? Green urban development, environmental gentrification, and the Atlanta BeltLine. Urban Geogr. 2018, 39, 546-562. [CrossRef]

50. Rigolet, A.; Nemeth, J. "We're not in the business of housing": Environmental gentrification and the nonprofitization of green infrastructure projects. Cities 2018, 81, 71-80.

51. Haase, A.; Rink, D. Inner-city transformation between reurbanization and gentrification: Leipzig, Eastern Germany. Geography 2015, 120, 226-250. [CrossRef]

52. Schwarz, N.; Bauer, A.; Haase, D. Assessing climate impacts of planning policies-An estimation for the urban region of Leipzig (Germany). Environ. Impact Assess. Rev. 2011, 31, 97-111. [CrossRef]

53. Ali, L.; Haase, A.; Heiland, S. Gentrification through Green Regeneration? Analyzing the Interaction between Inner-City Green Space Development and Neighborhood Change in the Context of Regrowth: The Case of Lene-Voigt-Park in Leipzig, Eastern Germany. Land 2020, 9, 24. [CrossRef]

54. Hillbrandt, H. Everyday urbanism and the everyday state: Negotiating habitat in allotment gardens in Berlin. Urban Stud. 2019, 56, 352-367. [CrossRef]

55. Rall, E.; Bieling, C.; Zytynska, S.; Haase, D. Exploring city-wide patterns of cultural ecosystem service perceptions and use. Ecol. Indic. 2017, 77, 80-95. [CrossRef]

56. Bendt, P.; Bartel, S.; Colding, J. Civic greening and environmental learning in public-access community gardens in Berlin. Landsc. Urban Plan. 2013, 109, 18-30. [CrossRef] 
57. Haase, D.; Haase, A.; Rink, D. Conceptualising the nexus between urban shrinkage and ecosystem services. Landsc. Urban Plan. 2014, 132, 159-169. [CrossRef]

58. Kinder, K. DIY Detroit: Making Do in a City without Services; University of Minnesota Press: Minneapolis, MI, USA, 2016.

59. Gross, A. Detroit Purchases 7.5 Miles to Build Greenway Loop. Available online: https://www.freep.com/ story/news/local/michigan/detroit/2017/06/22/detroit-conrail-build-greenway-trail/419529001/ (accessed on 5 November 2019).

60. Joe Louis Greenway. Available online: https://detroitgreenways.org/joe-louis-greenway/ (accessed on 29 July 2020).

61. A City to Yourself. Available online: https://www.imdb.com/title/tt8810922/?ref_=nm_ov_bio_lk1 (accessed on 18 December 2019).

62. Detroit Future City. Available online: https://detroitfuturecity.com/ (accessed on 29 July 2020).

63. Kirkpatrick, L.O. Urban Triage, City Systems, and the Remnants of Community: Some "Sticky" Complications in the Greening of Detroit. J. Urban Hist. 2015, 4, 261-278. [CrossRef]

64. Clemen, D.; Kanai, M. The Detroit Future City: How Pervasive Neoliberal Urbanism Exacerbates Racial Injustice. Am. Behav. Sci. 2014, 59, 369-385. [CrossRef]

65. American Forests. American Forests Urban Ecosystem Analysis SE Michigan and City of Detroit; American Forests: Washington, DC, USA, 2006. Available online: http://www.systemecology.com/4_Past_Projects/AF_ Detroit.pdf (accessed on 7 May 2019).

66. Woiwode, T. The Dequindre Cut: An Homage to the Past and Symbol of Detroit's Future. Available online: https://www.freep.com/story/opinion/contributors/2016/05/01/dequindre-cut-detroitfuture/83702990/ (accessed on 8 May 2019).

67. Silverman, R.M.; Taylor, H.L.; Yin, L.; Miller, C.; Buggs, C. Are We Still Going through the Empty Ritual of Participation? Inner-City Residents and Other Grassroots Stakeholders' Perceptions of Public Input and Neighborhood Revitalization. Crit. Sociol. 2019. [CrossRef]

68. Meerow, S.; Newell, J. Urban resilience for whom, what, when, where, and why? Urban Geogr. 2016, 40, 309-329. [CrossRef]

69. Ignatieva, M.; Hedblom, M. An alternative green carpet: How can we move to sustainable lawns in a time of climate change? Science 2018, 362, 148-149. [CrossRef]

70. Rupprecht, C.D.D.; Byrne, J.A. Informal Green Space as an Anti-Gentrification Strategy. In Just Green Enough: Urban Development and Environmental Gentrification; Curran, W., Hamilton, T., Eds.; Routledge: New York, NY, USA, 2018; pp. 209-226.

71. Foster, A.; Newell, J. Detroit's lines of desire: Footpaths and vacant land in the Motor City. Landsc. Urban Plan. 2019, 189, 260-273. [CrossRef]

72. Kabisch, N.; Haase, D. Green justice or just green? Provision of urban green spaces in Berlin, Germany. Landsc. Urban Plan. 2014, 122, 129-139. [CrossRef]

73. Rigolon, A.; Christensen, J. Greening without Gentrification: Learning from Parks-Related Anti-Displacement Strategies Nationwide. Available online: https:/www.ioes.ucla.edu/wp-content/uploads/Greening-withoutGentrification-report-2019.pdf (accessed on 16 June 2020).

74. Van der Ryn, S.; Cowan, S. Ecological Design; Island Press: Washington, DC, USA, 1996.

75. Fullilove, M.T. Urban Alchemy: Restoring Joy in America's Sorted-Out Cities; New Village Press: New York, NY, USA, 2013.

(C) 2020 by the authors. Licensee MDPI, Basel, Switzerland. This article is an open access article distributed under the terms and conditions of the Creative Commons Attribution (CC BY) license (http://creativecommons.org/licenses/by/4.0/). 